\title{
The place of psychodynamic theory in developmental psychopathology
}

\author{
PETER FONAGY AND MARY TARGET \\ University College London
}

\begin{abstract}
Psychoanalysis ushered in this century. Will its influence on developmental psychopathology end in the next? The paper explores some critical obstacles in the way of psychodynamic research, including the fragmentation of psychoanalytic theory, the relative independence of theory from its clinical and empirical base, the predominance of inductive scientific logic, the polymorphous use of terms, the privacy of clinical data, the dominance of the reconstructionist stance, and the isolation of psychoanalysis from psychology and neurobiology. Notwithstanding these limitations, core psychoanalytic precepts are not only consistent with some of the most important advances of the last decade but may also be helpful in elaborating these new discoveries in the next century. Psychoanalysis is centered on the notion that complex, conflicting, unconscious representations of mental states constitute a key facet of normal and abnormal development. This notion retains its power, and deserves a prominent position among the major frames of reference to guide developmental science in the next century.
\end{abstract}

The future of psychoanalysis, if it is to have a future, is in the context of an empirical psychology, abetted by imaging techniques, neuro-anatomical methods, and human genetics. Embedded in the sciences of human cognition, the ideas of psychoanalysis can be tested, and it is here that these ideas can have their greatest impact. (Kandel, 1998, p. 468)

Few would question that psychoanalytic theory, and particularly Freud's ideas, have exerted a profound effect on 20th-century thought; an equally small minority would consider its impact on the 21 st century as assured. There have been numerous obituaries of psychodynamic thinking over the past decade (Grünbaum, 1984; Webster, 1995). Frederick Crews (1993) is perhaps representative. Crews asserts that psychoanalytic theory is without significant experimental or epidemio-

Address correspondence and reprint requests to: Peter Fonagy, PhD, Psychoanalysis Unit, University College London, Gower Street, London WC1E 6BT, UK; E-mail: p.fonagy@ucl.ac.uk. logical support, that any body of knowledge built on Freud's dubious insights is likely to disappear into quicksand, and that "despite some well-intentioned efforts at reform a pseudoscience is what psychoanalysis has remained" (p. 55).

Attacks on Freud's corpus are by no means new. John Watson (1930) predicted that "20 years from now an analyst using Freudian concepts and Freudian terminology will be placed on the same plane as a phrenologist" (p. 27) and thus ushered in what is generally regarded as the heyday of psychoanalytic ideas. However, the pervasiveness and intensity of recent critiques cannot be shrugged off even by the most committed Freudian zealots. Before a psychodynamic approach to developmental psychopathology can move into the next century, it must deal with the challenges it faces and undertake radical reappraisal of its epistemic framework. It is argued herein that if such a reorientation is possible, the psychodynamic approach could make a timely and significant contribution to the progression of ideas in developmental psychopathology. 


\section{Critiques of the Psychodynamic Approach}

The difficulties faced by psychodynamic thinking are both external and internal. External challenges include poor evidence of treatment effectiveness; the building of developmental theory from retrospective accounts extrapolated from a clinical population; pervasive gender, cultural, and ethnic biases; the failure to integrate data from the biological and social sciences; and a focus on the individual to the exclusion of social and cultural forces. As these external challenges are quite well publicized (Frosh, 1997), this review will begin with the internal battles that need to be addressed if psychoanalysis is to remain influential in the 21st century.

\section{Internal problems}

Over recent decades psychoanalysts have witnessed an increasing fragmentation of theory. Arguably, the major psychoanalytic schools that emerged following Freud's death, and that have organized the discipline since (Fonagy, Target, Steele, \& Gerber, 1995), are breaking apart. This fragmentation, euphemistically discussed as pluralism, could on its own spell the demise of psychoanalysis.

Why might this happen? Elsewhere (Fonagy, in press) we have argued that a major problem with psychodynamic theory building lies in its relationship to clinical practice. Psychoanalysts have always argued, and we agree, that psychoanalytic treatment provides a unique window on human behavior and experience, which generates developmentally rich and clinically powerful accounts. The main function of theory for practitioners is in explaining clinical phenomena. The weakness of such clinical theories is their extensive reliance on induction. ${ }^{1}$ A theory is used as a heuristic device rather than as a tool for deduction. The clinical usefulness and persuasiveness of inductive arguments can lead us, with the greatest of ease, to raise the status of "clinical theories" to laws, gaining the im-

1. There is some truth to the quip that psychoanalytic clinicians understand the word data to be a plural of the word anecdote. pression as we do so that we have a tool for understanding that not only makes sense to us but also works for our patients and is furthermore scientific. ${ }^{2}$

There are several conditions that should be met for the accumulation of clinical observations to become a genuinely adequate basis for psychoanalytic theory. These are: (a) a clear logical tie between theory and technique, so that the inevitable contamination of observations by technique can be identified and studied; (b) deductive as well as inductive reasoning in relation to clinical material; (c) the unambiguous use of terms in labeling clinical observations; (d) a willingness to expose more clinical work to detailed scrutiny and, therefore, to different theoretical perspectives; (e) reconsideration of the reconstructionist approach, since there are logical pitfalls in building theory on the basis of remembered events; and (f) good contact and collaboration between psychoanalysts and those working in neighboring disciplines. We think it is vital that psychoanalysis should not continue to insulate itself from related fields of work; there is much to be learned from both sides, as we strive to indicate. None of these criteria has yet been adequately met, and in the following sections we discuss some implications of this situation.

\section{Psychodynamic clinical practice is not logically deducible from any psychoanalytic clinical theory}

Psychoanalytic technique is not logically connected to theory (e.g., see Berger, 1985); there are several aspects to this, some of which are touched on below.

1. Psychoanalytic technique arose largely on the basis of trial and error, rather than hav-

2. In fact, most clinical laws are, in any case, only probabilistic (Ruben, 1993). Therefore, they could allow only inductive statistical explanations rather than deductive-nomological ones (see Carl Hempel's 1965 Covering-Role Model). While we know that child maltreatment can give rise to behavioral disturbance, this is by no means inevitably the case (e.g., Cicchetti \& Rogosch, 1997; Cicchetti, Rogosch, Lynch, \& Hoot, 1993). 
ing been driven by theory. Freud (1912) willingly acknowledged this: "The technical rules which I am putting forward have been arrived at from my own experience in the course of many years, after unfortunate results had led me to abandon other methods" (p. 111).

2. There is no one-to-one correspondence between differing psychoanalytic frameworks and the techniques used. It is as easy to illustrate how the same theory can generate different techniques as how the same technique may be justified by different theories (Wallerstein, 1992). For example, Gedo (1979) states that "principles of psychoanalytic practice ... [are] . . based on rational deductions from our most current conception of psychic functioning" (p. 16). His book claims that developmental problems can be reversed "only by dealing with those results of all antecedent developmental vicissitudes that later gave rise to maladaptation" (p. 21). However, what sounds like a deduction on closer examination turns out to be a hypothesis. It is one thing to presume and quite another to demonstrate that therapy requires developmental vicissitudes to be addressed sequentially. Many have powerfully challenged the overuse of the developmental metaphor (Mayes \& Spence, 1994) and, even from within the self-psychology orientation to which Gedo belongs, the support for his strong assertion is limited (Kohut, 1984, pp. 42-46).

3. Theory and practice have developed at very different rates, with practice changing only in minor ways during the 20th century, in contrast to the major strides made by theories. It is quite realistic to contemplate a single volume account that would encompass most major technical advances, ${ }^{3}$ yet no single person could do justice to all the enormous theoretical developments that have taken place over the same period. The discrepancy in rates of change is staggering and would be hard to understand were it

3. This has always been the case: only 1 volume of Freud's 23-volume corpus is devoted to papers on technique. not for the relative independence of theory and practice.

\section{Inductive rather than deductive reasoning is used in relation to clinical material}

The predominant theory-building strategy in clinical psychoanalysis is "enumerative inductivism" (the accumulation of instances consistent with a premise). In treating a patient, we have access to a set of observations, certain of which are selected as telling. From these the analyst draws conclusions about how the patient generally behaves and why he or she does so. The analyst will be predisposed to focus on those aspects of the patient's interaction which make sense in terms of existing theoretical constructs. Induction is thus made not just from the accumulation of observations about a particular individual but also from formulations of past cases by other psychoanalysts.

From a clinical point of view this is useful. The difficulty arises from our understanding, as clinicians, of the role of theory. We consider it to lend credence to inductive observations because we assume that theories have been inferred from a very large number of observations and subsequently tested against new, independent observations. What we can find ourselves doing instead, however, is piling induction on untested induction.

Thus, theory is intrinsically contaminated by the technique used to generate observations. Theory has been shaped by what has been found clinically helpful, rather than practice being dictated by what is true about the mind. Thus, while theory is a vital adjunct to clinical practice, neither has been used in a way that would have helped to validate the other. We almost certainly miss many instances when the patient's reaction is not as we would have anticipated on the basis of a theoretical formulation, and we therefore do not use the disconfirmations to improve or discard psychoanalytic theories. Psychoanalysts are not alone with this problem. Not only most clinical thinking, but in fact all human reasoning shares this flaw (Johnson-Laird \& Byrne, 1993; Wason \& Johnson-Laird, 1972). 
To take a simplistic example, signs of unconscious anger-displaced onto the self and away from someone ambivalently loved and now lost - are easily found in cases of depression, and Freud's description (1915) remains clinically compelling. But what of cases where we can see the inward direction of anger, but it does not lead to depression? Such cases could have been used to test and extend the psychoanalytic theory of depression. To ask clinicians (and this applies not only to psychoanalysts) to note and act on such negative instances, however, seems to introduce something alien to the therapeutic process, setting therapeutic and research aims against each other. Despite a few great exceptions such as Freud, this confirmatory bias may be fatal, in most cases, to the popular notion of clinician as researcher.

This logical difficulty in selecting between theories is the primary reason for their proliferation. As clinical observations are used inductively by theorists who are themselves clinicians, new psychodynamic theories readily emerge and obtain some confirmation. New theories are seen as supplementing rather than replacing older ones (Sandler, 1983), so that numerous partially incompatible formulations need to be combined to provide comprehensive accounts. Thus, at any time psychoanalytic theory is like a growing family of ideas, with resemblances, relationships, and feuds. If a psychoanalytic approach is to survive, then there must be ways of pruning this family tree, so that the body of theory is strengthened rather than continually branching out.

\section{The ambiguous use of terms}

Perhaps in order to accommodate proliferating ideas, the definition of theoretical terms has been left vague (Sandler, 1983). This is neither unusual nor easily avoided. It is the way that human language and all human conceptual systems deal with the complexity of the phenomena they represent (Rosch, 1978; Wittgenstein, 1969). However, the absence of operational definitions may obscure important differences between theoretical approaches.

The definition of concepts in psychodynamic theories admittedly poses a formidable challenge. Most of the concepts are private; many of them (e.g., "splits in the ego," masochism, and omnipotence) are complex and abstract. However, while the clarification of terms is laborious, it is possible (e.g., Sandler, 1962). It is also essential if we are to find out where theoretical differences are real, and where they may only be imagined.

\section{Allowing clinical observations to be shared and tested}

Clinicians' narrative reports are necessarily selective. We cannot expect any participant in an interaction to be unbiased, to introduce no omissions and distortions. Far more important than bias, however, is that interactions are largely governed by nonconscious mechanisms, unavailable to introspection. There are quite dramatic illustrations of this-Krause's (1997) studies of facial expressions in face-toface psychotherapy, and Beebe's (1997) and Tronick's (1989) work on mother-infant interaction. The crucial information was never consciously known to the participants, and could not have been reported, only observed.

There is a constant tension between making reliable, accessible observations and introducing an unacceptable interference into the process. We must do everything possible to gain informed consent, to protect confidentiality, and to ensure that observation creates minimal distortion. These are, however, not insuperable problems in other areas of psychotherapy research and need not be so for psychoanalysis (Jones, 1993).

\section{The reconstructionist clinical stance}

Clinical theories of development are mainly based on the accounts of people who have sought help for symptoms or other life problems, and who attempt to recall events that occurred during early childhood, the most relevant part of which covers the preverbal stages of development. There are two great dangers here: firstly, of a logical fallacy in assuming that something must have gone amiss during childhood, and, secondly, of an empirically discredited assumption that remembered events are "true." (Psychoanalysis 
has contributed significantly to our knowledge about sources of bias that can strongly distort early memories: see Brewin, Andrews, \& Gotlib, 1993; Fonagy \& Target, 1997.)

It should not, however, be too readily assumed that empirical data are necessarily more helpful than clinical data in the construction of a psychological theory. Westen (1991) points to the relative paucity of rich theories within current psychiatry and psychology that are based on controlled studies. Indeed, many psychological theories and empirical investigations of psychopathology explicitly acknowledge their indebtedness to psychoanalytic ideas. Clinical data offer a fertile ground for theory building but not for distinguishing good theories from bad or better ones. The convergence of evidence from several sources (e.g., clinical, experimental, behavioral, epidemiological, and biological) will provide the best tests of the claims of psychoanalysis (Fonagy, 1982).

\section{Psychoanalysis has been too isolated from neighboring disciplines}

Psychoanalysts over the last 50 years have attempted to define their field independently of two major neighboring branches of scientific activity: (a) psychology and (b) neurobiology. We believe that this insular approach now needs to be challenged.

Psychoanalysis and psychology. Progress in psychology has been largely ignored by psychoanalysts, despite the fact that an increasing proportion of psychoanalysts have received their basic training in clinical psychology. (Surveys of the profession demonstrate that the proportion of psychologists among psychoanalytic trainees increased to $25 \%$ from a negligible percentage over the last decade: American Psychoanalytic Association, 1998.) Historically, there were valid reasons for this. Until the 1960s psychology espoused a positivist epistemology, was almost exclusively concerned with behavior and was highly antagonistic to psychoanalysis (Eysenck, 1952). As a result, clinical psychology embraced a simplistic and mechanistic approach to mental disorder abhorrent to psychoanalysts (Ullmann \& Krasner, 1969; Wolpe, 1969).

Psychology has, of course, changed, and now leads the scientific study of mental processes (Westen, 1999). Some changes particularly relevant to psychoanalysis include the development of (cognitive) therapeutic models in clinical psychology, which recognize the influence of nonconscious processes on emotional states; the harnessing of technology for the recording of interaction; and the development of methods for studying transgenerational influences on personality development.

The current generation of psychoanalysts is returning to an appreciation of systematic observational and developmental studies. Such studies were begun by Freud (see Freud, 1909a, 1919, 1920) and were continued by Anna Freud, René Spitz, Margaret Mahler, Esther Bick, Donald Winnicott, and others. However, these studies fell out of favor with psychoanalysts when taken up by apparently alien scientific disciplines. In the next century, we can expect that developmental studies will be increasingly recognized as allowing us to test psychoanalytic theories. For example, in the mid-20th century, Melanie Klein was roundly condemned for making extravagant claims for the capacities of infants, but recent observational evidence of their cognitive capacities has given some support to her ideas (Gergely, 1991).

There is a further problem concerning psychological therapies. The pressure for cheaper and quicker treatments has prompted some psychoanalysts to experiment with alternative methods-briefer, more focused therapies, and special therapies for particular groups (e.g., Malan \& Osimo, 1992). The psychoanalytic establishment, presumably concerned about superficiality, has on the whole ignored these experiments. The gap has rapidly been filled by alternative therapies, with often limited observational or theoretical basis, borrowing increasingly heavily, and sometimes openly, from psychoanalysis (e.g., Ryle, 1994). Both the discoveries and the effects of cognitive behavioral and even behavior therapy are as easy to explain in terms of psychoanalytic ideas as in terms of social learning theory (Fonagy, 1989). It is regrettable that 
more psychoanalysts have not tried to evolve new psychotherapeutic techniques, rather than sticking to a "one size fits all" principle.

This situation has altered somewhat, and the changes are very likely to accelerate. Many American institutes of psychoanalysis have started training psychotherapy candidates, only some of whom are expected to go on to full psychoanalytic training. Others have accepted directly the challenge of alternative therapies and are working towards either integrating effective components of these into psychoanalytically oriented treatments (Goldfried, 1995) or differentiating the effective elements of each (e.g., Jones, 1997).

Psychoanalysis and neurobiology. With notable exceptions, psychoanalysts have disregarded the relevance of neurobiology to psychoanalytic ideas. The rejection of biology was not arbitrary but reasoned-not political but conceptual. Psychoanalysts were powerfully influenced by Freud's failure to create a psychoanalytic neurobiology (Freud, 1895) and opted for a purely mental model based around verbal reports of internal experience. In the 1940s and 1950s neurobiology was dominated by mass action theory (Lashley, 1929), which held that the cortex was largely indivisible from a functional point of view and behavior could not be usefully studied from the point of view of the brain.

Neuroscientists were, by and large, unconcerned with mental health problems, their focus being on deficits of cognitive functioning rather than affect regulation. Psychoanalysis began in radical opposition to a prevailing view that mental disorders represented a constitutional irreversible vulnerability of the individual. An unhelpful distinction between so-called functional and organic disorders was then developed within psychiatry and other mental health professions, which (although rarely scrutinized from this point of view) implied mind-body dualism, again something Freud had rejected.

While-in terms of developing the discipline with its focus on unconscious determinants-it may have been helpful to isolate psychoanalysis from the brain sciences, in the last 30 years advances in all the neurosciences have negated the reasons for this (Westen, in press-a). Neuroscientists are no longer concerned just with cognitive disabilities or socalled organic disorders (Kandel, 1998; LeDoux, 1995a). If Freud were alive today, then he would have been greatly interested in new knowledge about brain functioning, such as the development of neural nets, and the location of specific capacities with functional PET scans, and he would surely not have abandoned his cherished Project (Freud, 1895) to develop a neural model of behavior. Genetics has progressed, if anything, even more rapidly, and mechanisms which underpin and sustain a complex gene-environment interaction belie early assumptions about constitutional disabilities (Plomin, DeFries, McLearn, \& Rutter, 1997). In fact, for the past 15-20 years the field of neuroscience has been wide open for input from those with an adequate understanding of environmental determinants of development and adaptation.

Sadly, the response of psychoanalysts has been more defensive than welcoming of these remarkable advances. The anxiety appears to be that hard-won psychoanalytic insights could be damaged rather than enriched by new methods of inquiry (Green, 1999). However, there are encouraging signs that this is changing; see, for instance, the excellent series of detailed papers on developments in neuroscience published by the International Journal of Psycho-Analysis in the last few years, and the establishment of new journals bridging psychoanalysis and neuroscience.

\section{The Promise of Psychoanalysis}

Given the limitations of psychoanalytic theory, an obvious question is why developmental psychopathology should concern itself with this flawed and apparently outdated approach. We intend here to examine first whether psychoanalysis is compatible with new knowledge emerging from genetics and other related fields, and whether its discoveries could be integrated with the progress being made elsewhere. Only if it is does it seem worth considering whether psychoanalysis has additional features which entitle it to exert an influence in the coming decades. 


\section{The challenge of genetics}

Over the last decade, research in genetics appeared to have all but eliminated the place for a psychoanalytic account and refuted all theories that advocated the key role of early family experience (see Scarr, 1992). There has been a claim that environmentally mediated family influences were inherited and therefore in themselves unimportant (Rowe, 1994) and that insofar as family environment mattered, it was specific to each child, even within the same family (Plomin \& Daniels, 1987). It has also been suggested that influences, previously considered environmental, were actually genetically mediated (Kendler et al., 1996) and, further, that some genetically influenced aspects of children's behavior may have been responsible for provoking observed negative responses in parents and other people (O'Connor, Deater-Deckard, Fulker, Rutter, \& Plomin, 1998). Finally, all estimates for the heritability of psychiatric disorders increase when lifetime risk, rather than point prevalence, is used as an index variable (Kendler, Neale, Kessler, Heath, \& Eaves, 1993). All in all, a cultural shift characterizes the last decade of this century, with both professionals and the lay public switching from a primarily psychosocial model of child and adult disturbance to a genetic-biological frame of reference that a priori excluded consideration of psychodynamic aspects.

A more balanced view of these genetic data was advanced by Michael Rutter and colleagues (Rutter et al., 1997), and this has reestablished the potential for psychoanalytic accounts. The main features of this view are outlined below.

1. Virtually all forms of psychopathology involve both gene-environment correlations and interactions. However, these correlations do not necessarily imply an etiological role for genetics. Individuals affect the environment and some gene-environment covariance may be due to person characteristics, irrespective of whether these person characteristics are genetic or environmental in origin (O'Connor et al., 1998).
2. The notion of nonshared environment includes two components: firstly, the extent to which key parameters within a shared environment may differ in relation to a specific child, and, secondly, the extent to which shared environments may be experienced differently by two children. Neither of these pathways necessarily involves genetic mediation.

3. Neither twin studies nor adoption studies can provide firm indications of the relative importance of genes and environment. They provide estimates of individual difference within a population. For example, while height is clearly heritable, changes in average height over the past 100 years (in excess of $1 \mathrm{ft}$ for males) reveal that much of the variability must be attributable to the environment. Secular trends over the past 50 years reveal a substantial increase in the prevalence of a number of childhood mental disorders (e.g., antisocial disorder, suicidal behavior, depressive disorder, and misuse of drugs; see Rutter \& Smith, 1995). Twin studies, where children's ages are identical, cannot reflect the critical environmental influences implicit in such secular trends.

4. Heritability estimates are dependent on the samples studied. Samples are mostly biased and exclude environments that are most likely to be associated with deviations of personality development. Gene-environment correlations imply that discrepancies between the environments of twins are likely, in any case, to be relatively small. Cultural factors are also mostly partialed out: if individuals from a variety of cultures were to be included in the same study, our estimates of the likely impact of shared environment on personality would be very different (Mandler, 1997).

5. Genetic effects may well be indirect as well as direct. Even a high genetic loading for a certain environmental hazard does not mean that the consequences associated with that risk factor would necessarily be genetically rather than environmentally mediated. For example, if child abuse were found to 
have a large genetic component, its toxic effects would still be via the destruction of trust in the abused child rather than via a purely genetic process.

6. Studies that attempt to exclude direct and indirect genetic effects still reflect the considerable influence of early experience. For example, a study of adult female twins demonstrated that a history of parental loss through separation, though not through death, was associated with adult vulnerability to depression and alcoholism (Kendler et al., 1996). A recent well-controlled prospective study showed that childhood maltreatment was associated with a 9-fold increase in the risk of personality disorders of a dramatic type (Johnson, Cohen, Brown, Smailes, \& Bernstein, 1999).

We believe that in general the challenge of genetics over the last decade has been a helpful one for the psychodynamic approach. It has served to balance the naive environmentalism of the second half of this century, which culminated, for example, in the overdiagnosis of posttraumatic stress disorder among victims of childhood maltreatment and gave rise to the unfortunate debate on false memories of abuse (Sandler \& Fonagy, 1997). Psychodynamic theory, which is inherently person centered, has much to contribute to the integration of genetics into developmental science. The primary concern of psychoanalysis is with the interaction of multiple layers of representations in generating developmental outcomes (e.g., id, ego and superego, part and whole object representations). Data from genetics call for exactly such sophistication in understanding the way genes may or may not be expressed in particular individuals. For example, while risk factors operate in combination, there is substantial individual variability in response to stress and adversity. Much of this variability is poorly understood (Rutter, 1999), but it underscores the potential importance of intrapsychic variables. Whether or not the specific environmental factors trigger the expression of a gene may depend not only on the nature of those factors but also on the way the child experiences them. This may in turn be a function of either genetic or environmental influences, or their interaction (Kandel, 1998). Thus intrapsychic representational processes are not just consequences of environmental and genetic effects - they may be critical moderators. This has substantial clinical significance, since the understanding of an environment by the child is more readily modifiable than the environment itself, or the genes with which the environment interacts (Emde, 1988). A psychodynamic, intrapsychic perspective may be helpful in considering not just what precipitates a disorder but also which processes influence the course of the disorder for better or worse.

\section{Unconscious intentionality}

The hallmark of psychoanalytic theory is the attention to unconscious mental processes and unconscious motivation in the explanation of complex and often paradoxical human behavior. We suggest that knowledge concerning unconscious mental processes and motivations could be integrated into the emerging science of the mind, to which developmental psychopathology remains a key contributor. As some philosophers have relatively recently concluded, Freud's brilliant insights may be seen as extensions of common sense or folk psychology (Churchland, Ramachandran, \& Sejnowski, 1994) to unconscious mental functioning (Hopkins, 1992).

Cognitive neuroscience has shown that most of the work of the brain is nonconscious (Kihlstrom, 1987). This is now known to include not only memory acquired implicitly (without conscious awareness; e.g., see Milner, Squire, \& Kandel, 1998) but also implicit aspects of thought, decision making, problem solving, and other cognitive tasks (e.g., Underwood, 1996). Freud (1900), having recognized the importance of this fact in the development of psychopathology, advanced two radical propositions which go beyond the current position of neuroscientists. First, mental health problems could be understood in terms of unconsciously held mental states (beliefs and desires; Freud \& Breuer, 1895). Second, effective treatment of mental health problems could be undertaken if (and only if) the indi- 
vidual suffering from mental disorder was made aware of these unconscious, and by definition maladaptive, beliefs or desires (e.g. Freud, 1909b).

Freud's arguments for moving the study of mental disorder and its treatment to the level of psychological causation were sound and remain broadly consistent with research evidence (see below). Unfortunately, he overspecified his model and moved beyond general statements on the role of unconscious belief and desire and attempted to specify ideas that, in his view, commonly created unconscious conflicts and led to problems of adaptation (e.g., unconscious conflicts concerning toilet training; see Freud, 1905). In a developmental context, Anna Freud (1974) went further and linked types of childhood mental health problems and categories of unconscious conflict. For example, she was persuaded by clinical experience that childhood phobias were associated with unresolved oedipal conflicts and that obsessive-compulsive neurosis was related to the child's unconscious conflicts around early potty training.

Such overspecification of a good theory had to be counterproductive. The range of psychosocial experiences that reach a common symptomatic end point is probably limitless (i.e., equifinality; see Cicchetti \& Rogosch, 1996). Similarly, the same experience may well lead to a variety of clinical manifestations (e.g., Fergusson \& Lynskey, 1996). Unfortunately, in overspecifying his theory, Freud laid psychoanalysis open to endless revisions and updating of aspects of theory which were never core to his ideas (Fonagy et al., 1995). For example, the influential child analyst Melanie Klein was struck by the apparent destructiveness and cruelty manifested by normal infants (Klein, Heimann, Issacs, \& Riviere, 1946). She attributed highly complex ideas (envy, paranoia, guilt, and the capacity for denial) to babies under 1 year of age, and saw these as central to later pathology. Others, focused on somewhat later developmental periods (e.g., Mahler, Pine, \& Bergman, 1975), specified key conflicts quite differently (in this case, symbiosis, separation-individuation, etc.).

We are not suggesting that either of these models was wrong. We happen to believe that both destructive envy and conflicting wishes for separateness and union are important ideas for understanding mental distress. The problem is one of trying to claim exclusivity for any of these ideas. Here we are not pleading for an integrationist model (Goldfried \& Newman, 1992). Rather, we are suggesting that Freud's original rich elaboration led later psychoanalysts to conflate the framework of psychological mechanisms implied by the theory with the specific mental contents that he used to populate his intellectual framework. Unconscious conflict is core theory. Envy, oedipal rivalry, separation-individuation conflicts, and narcissistic traumata are elaborations at a different level-one of clinical observation-and are therefore too confounded with practice to permit deductive inferences to developmental psychopathology.

Where the psychoanalytic position remains unique is in suggesting that motivational and affective processes that influence developmental processes may be unconscious. It is puzzling that this should be so since the role of cognition in emotion and motivation is well established (Mandler, 1997), and, therefore, almost by definition, affect and motivation should be part of the "cognitive unconscious" (Kihlstrom, 1987). Neurological evidence has been accumulating to suggest that neural pathways for emotion entail two sets of structures. One is via the thalamus to the amygdala (which conveys primitive perceptual information with affective valence but without the involvement of consciousness), and the other involves the activation of cortical centers and deeper information processing prior to the activation of the amygdala (LeDoux, 1995b). Patients with a variety of lesions who lose the capacity for conscious discrimination may retain the capacity to respond differentially at the emotional level (e.g., Bechara et al., 1995). There is evidence from nonneurological patients for unconscious affective preferences using low signal-to-noise ratio stimuli (e.g., Murphy, Monahan, \& Zajonc, 1995). Conditioned emotional responses may be elicited and even acquired (Wong, Bernat, Bunce, \& Shevrin, in press) outside of awareness. Unconscious attitudes, particularly ra- 
cial prejudice, have been persuasively shown to influence not only the speed of information processing but also the reactions generated in independent observers (Fazio, Jackson, Dunton, \& Williams, 1995).

These and other findings, recently comprehensively summarized by Westen (in press-b), support the view that emotional processing occurs unconsciously in an automatic way. Preliminary data also support the view that the unconscious processing of emotional information may be qualitatively different from its conscious processing, in terms of the neural mechanisms involved (Morris, Ohman, \& Dolan, 1998), its psychophysiological concomitants (Dozier \& Kobak, 1992), and its behavioral consequences (Greenwald \& Banaji, 1995). To the extent that unconscious as well as conscious factors have a role to play, then abnormalities in unconscious functioning, as postulated by psychoanalysis, will remain highly significant. Developmental psychopathology will need to integrate this perspective on maladaptation.

\section{Unconscious motivation}

Of course, admitting that affects may not be conscious is not equivalent to stating that unconscious mental states motivate behavior. Although unconscious motivation is not generally considered by developmental psychopathologists, aside from those with preexisting psychoanalytic leanings, it is neither an extravagant assumption nor one unsupported by other sources of data. Westen (in press-b) pointed out that the assumption that human behavior is simultaneously motivated by multiple goals implies that the logical mechanism for organizing these must exclude consciousness, because of the excessive demands these would make on working memory.

There is considerable evidence consistent with this view. For example, intending to carry out an action will lead to heightened activation of the information to be remembered even when the intention is no longer conscious, as evidenced by response latencies for recognizing to-be-remembered items from a list (Goschke \& Kuhl, 1993). A range of stud- ies have demonstrated that when people act on motives or preferences to which they have no access, they will find reasons for having done this which are both incorrect (Nisbett \& Wilson, 1977) and likely to interfere with subsequent task performance (Wilson \& Schooler, 1991).

The value of the concept of unconscious affect as motivation is strongest in explanations of psychological disturbance. Psychoanalytic theorists assume that development, both adaptive and maladaptive, is best understood in terms of the "competition, collaboration and conflict among quasi-independent psychological events" occurring outside awareness (Westen, in press-a). Westen makes a strong case that the psychodynamic model is in line with contemporary connectionist or parallel distributed processing (PDP) models in cognitive science (Rumelhart \& McClelland, 1986). Both psychodynamic and PDP models postulate multiple independent processing units that work alongside each other, at times in conflict, at times in collaboration, to generate both conscious and unconscious decisions. Within the PDP model, conflict is an "emergent property" of the human nervous system. The constraints placed upon the system are both external (context dependent) and internal (emotional and motivational). It follows from the independence of neural circuitry underlying the generation of individual mental states (beliefs, desires, fears, values) that these states may be opposed to one another. It further follows from developmental localizationist perspectives consistent with PDP (Kinsbourne \& Hicks, 1979; Schore, 1999) that several neural processing nets emerge early and simultaneously in development to perform the same psychological function. This ensures plasticity and protects the organism from the consequences of brain injury.

In the course of development and the increasing involvement of specific brain locations with specific tasks, connections between some of these nets and processing units on the periphery of the evolving system (at greater cortical distance from the point of localization) will be increasingly marginalized (Edel- 
man, 1992). As feedback to such systems is degraded by cortical distance, the processing characteristics of these vestigial systems will not be updated in line with neural nets that are closer to the focal area responsible for specific tasks. These vestigial nets will therefore remain archaic in their functioning. Thus conflict between the output of central and peripheral processing units, with processing characteristics reflecting varying levels of maturity, may be inevitable.

Consistent with the notion of relative independence of neural circuitry for a variety of emotional and motivational states is the accumulating body of knowledge concerning the neural circuitry responsible for positive and negative affect states (Davidson, 1992; Gray, 1990). The complexity of interpersonal interactions, in terms of the concurrent presence of both positive and negative affect, has been demonstrated (Hartup \& Stevens, 1997). The development of cognitive-emotional structures that resolve incompatibilities in emotional information processing represents a key developmental goal. For example, in the social referencing task, 12-month-olds respond with distress and confusion if they receive conflicting facial messages from their two parents (Hirshberg \& Svejda, 1990). The failure to resolve conflict in relation to the anticipated behavior of the attachment figure is a key part of models of disorganized attachment (Lyons-Ruth \& Jacobovitz, 1999; Main \& Morgan, 1996). Psychoanalytic models of psychopathology mostly entail the notion of compromise formation (Brenner, 1982). NeoPiagetian developmental theory (Fischer \& Ayoub, 1994) also assumes that development is a stepwise integration of independently evolving cognitive capacities.

Thus, both neuropsychological and developmental models are consistent with psychoanalytic ideas concerning the coexistence of processing units from different developmental stages, the ubiquity of conflict between them, and the desirability of adaptive resolution of these conflicts as part of the developmental process. Psychoanalytic theories of conflict may have much to contribute to the study of development in the coming years.

\section{Early childhood experience}

Of greatest direct relevance to developmental psychopathology is the role of early childhood experience in determining adult personality. This has been a key tenet of all psychoanalytic propositions. The issue has been hotly debated within psychology (Rutter, 1999). Reviews in the 1980s concluded that there were few serious long-term sequelae of adverse childhood experiences that were clearly independent of later adversities (Rutter, 1981). Later research, however, demonstrated that early experiences did exert long-term effects (Sroufe, Egeland, \& Kreutzer, 1990), but these stemmed from (a) their contribution to the generation of further negative experiences (Sroufe \& Fleeson, 1988) and (b) rendering these individuals more vulnerable to such experiences (Rutter, Champion, Quinton, Maughan, \& Pickles, 1995; Suess, Grossmann, \& Sroufe, 1992). Psychodynamic theory might suggest that individuals with early adversity process their experiences differently and proactively create experiences compatible with past interactions (e.g., Caspi \& Moffitt, 1995). There is evidence that individuals who have encountered early adversity are more likely to encounter both acute and chronic psychosocial adversities in adult life (e.g., Champion, Goodall, \& Rutter, 1995).

An alternative model of the relationship of early experience and a predisposition to psychopathology, fully consistent with Freud's ideas (Freud, 1915), has emerged from the biological literature. Early stress (separation from its mother) in the life of a rodent pup led to enduring neuroendocrine abnormalities, whereas appropriate caregiving responses to the pup's distress led to a reduction in the pup's hypothalamic-pituitary-adrenal (HPA) response for the rest of the animal's life (Levine, Haltmeyer, Kaas, \& Penenberg, 1967). Intervening research has demonstrated that responsive caregiving serves, in the long term, to reduce the pup's fearfulness and vulnerability to stress-related disease (Liu et al., 1997; Plotsky \& Meaney, 1993). Other studies have demonstrated that early adverse life experiences in rats are associated with profound and 
persistent increases in gene expression for corticotrophin releasing factor (CRF), not only in the hypothalamus but also in limbic areas (Nemeroff, 1996; Plotsky \& Meaney, 1993). Independently, it has been demonstrated that increased secretion of glucocorticoids over a prolonged period can lead to permanent damage to hippocampal neurons (McEwen \& Sapolsky, 1995). These data provide an underpinning for the traditional psychoanalytic emphasis on the lifelong impact of very early attachment experiences.

Whether early environmental risk is carried forward primarily by the predisposition to select adverse environments (Farrington, Barnes, \& Lambert, 1996; Quinton \& Rutter, 1988), by maladaptive affect regulation, by neuroendocrine abnormalities, or by some combination of the three is not yet clear. However, all these models are consistent with psychoanalytical ideas (Kandel, 1999). In fact the psychological mechanisms implied may be the same regardless of the level of analysis (social or biological): such mechanisms might include unconscious biases in the processing of information, the absence of a capacity to plan (Quinton, Pickles, Maughan, \& Rutter, 1993), or distorted models of relationship representation (Fonagy et al., 1996). There is accumulating evidence that prolonged early and severe privation, particularly the absence of an attachment relationship, may have irreversible effects (O'Connor, Rutter, \& Kreppner, in press). A counterpoint to these observations is other evidence of the possibility of change-so called "turning point effects" (Caspi \& Moffitt, 1993). Psychotherapy would not be a viable option were it not for evidence that "experiences in adult life make a decisive difference to people who have been placed at risk as a result of adverse experiences in childhood" (Rutter, 1999, p. 487). The psychoanalytic focus on early experience has been demonstrated to be appropriate by research, and its depth-psychological perspective may illuminate outstanding questions.

\section{Mental representations and object relationships}

A key aspect of the psychoanalytic model of the mind, and the one where convergence with other measures is most marked (Westen, 1991), is the emphasis on mental representations of relationships as mediators of selforganization and as determinants of the impact of the environment on the individual. These representational structures are thought to mediate the experience of abnormal development. The concept emerged originally in the context of object relations theory, which has developed rapidly over the past 50 years (Fonagy et al., 1995). Numerous research methods have emerged to explore psychodynamic aspects of the child's representational world (e.g., Macfie et al., 1999; Oppenheim, Emde, \& Warren, 1997; Toth, Cicchetti, Macfie, \& Emde, 1997). There is accumulating evidence to suggest that children transform early interactions with primary caregivers into cognitive-affective schemas of self and other, which regulate and direct subsequent behavior (Bretherton \& Munholland, 1999). These schemata not only bear the imprint of significant interactions but also express the developmental level which dominates the individual's functioning (Westen, 1990). According to psychoanalytic theory, beyond representing consensual reality, internal working models contain the unique constructions of each child. Representations are distorted by defenses (Newman, Duff, \& Baumeister, 1997) and impulses (Westen, Muderrisoglu, Fowler, Shedler, \& Koren, 1997). These may be indications of a genetic predisposition or prior environmental experience. In either case, the child's distortion of the external world represents a significant challenge to studies aiming to find direct relationships between psychosocial adversity and psychopathology. Psychoanalytic object relations theory, with its focus on idiosyncratic distortions, may be able to make a significant contribution.

For example, Blatt and Blass (1996) have proposed that a dialectic between two developmental pressures defines the evolving representations of self-other relationships: the needs for (a) a sense of relatedness and (b) a sense of autonomous identity. These developmental processes are thought to be in synergistic interaction throughout development and a lack of balance implies psychopathology. "Anaclitic pathology" (an exaggerated need 
for relatedness) is present in dependent, histrionic, or borderline personality disorder; "introjective pathology" (an exaggerated quest for identity) is thought to characterize schizoid, schizotypal, narcissistic, antisocial, or avoidant individuals.

This person-centered approach deepens our understanding of psychiatric disturbance, as categorized by DSM-IV, from a developmental standpoint. For example, Blatt and Bers (1993) differentiate two types of depression: a dependent (anaclitic) and a self-critical (introjective) type. Thus depression in individuals with borderline personality disorder is characterized by emptiness, loneliness, desperation vis-à-vis attachment figures, and labile, diffuse affectivity. For nonborderline individuals with major depression, these aspects correlate negatively with the severity of depression, whereas for borderline individuals the same symptoms correlate almost perfectly with severity within the limits of the reliability of measurement (Rogers, Widiger, \& Krupp, 1995; Westen et al., 1992). Response to treatment is powerfully predicted by this distinction. For example, in the NIMH trial (Blatt, Zuroff, Bondi, Sanislow, \& Pilkonis, 1998; Elkin, 1994), individuals with perfectionism (introjective type) were unlikely to improve after the first few sessions, whereas patients with a high need for approval (anaclitic types) improved significantly in the second half of the treatment (Blatt, Quinlan, Pilkonis, \& Shea, 1995). The value of the psychoanalytic approach is highlighted by the fact that the majority of studies of depression neither explores nor differentiates between these groups, although the experience of psychological distress in the two groups is critically different. A person-centered approach that takes the representational world as its focus is helpful in refining our predictions.

\section{Close ties to interpersonal reality}

As psychoanalytic theory is rooted in clinical practice, the experience of the therapist provides a valuable vehicle for creating understanding of thoughts, feelings, and behavior that lie beyond the normal range of conscious experience and common sense psychology.
Psychoanalytic orientation, regardless of specific model, perhaps equips clinicians to handle and make sense of particularly intense and potentially disturbing human encounters. It is possible that the human understanding they offer is more complex and psychologically deeper than other so-called omnibus theories of human behavior (cognitive-behavioral, humanistic, systemic), even if psychoanalysis is therapeutically no more effective than these other approaches. Interpersonal interactions are complex, rapid, and beyond the capacities of the conscious mind to monitor or effectively guide beyond certain rudimentary strategies.

The work of Krause (1997) on the facial expression of affect in psychotherapy, for example, demonstrated that the success of psychotherapy was indexed by a subliminal affective interplay between therapist and patient. Congruent responses by the therapist (the therapist's tendency to match the patient's affect) was consistently associated with poor outcome. Complementary affective responses (the therapist tends to manifest an affect consistent with the patient's words but inconsistent with their facial display) predicted good outcome. The association with outcome held for cognitive behavior therapy as strongly as for psychodynamic treatment. Therapists are only aware of these split-second interchanges in terms of general subjective impressions. Allowing such intuitions to guide the therapeutic process is both the most cherished preserve and the greatest burden of the psychodynamic approach to treatment. The exploration of the limits of interpersonal awareness in the context of therapy may be the inherent appeal of psychoanalytic developmental ideas for clinicians, and may be part of the explanation for the continued popularity of an approach which is so vulnerable to criticisms on epistemic and empirical grounds. The tapping and matching of the sensitivity of the human mind as an instrument for the scientific study of development remains a challenge for the next century.

\section{The unique appeal of psychoanalysis}

To acknowledge the limitations of psychoanalytic epistemology is to tell but one half of a 
remarkable story. Some of the greatest minds ever to become interested in the subject of psychology, in particular the psychology of mental disorders, have adopted the frame of reference of psychoanalysis. We believe they did so not because they were drawn to an epistemology that was too loose to be able to reject new ideas but rather because psychoanalysis offered the richest and subtlest set of elements for describing the mind.

A number of its characteristics suggest that there is something important in this approach. First, there is a great deal of generativity within the field. Psychoanalytic ideas have inspired major psychological theories as well as important lines of empirical investigation (learned helplessness theory, schema theory, attachment theory, aggression and hostility as a cause of psychosomatic conditions, selfserving cognitive distortions - termed defense mechanisms by psychoanalysts-etc.). Second, psychoanalytic theories frequently offer attractive unifying explanations of diverse overt behavior by postulating a single underlying covert anomaly. For example, why are narcissistic individuals often forgetful of names, prejudiced, inconsiderate of others' time, and unable to remain in love? Psychoanalytic accounts, whether self-psychological or based on other object relations views, attempt to find a single explanation for such diverse phenomena. Third, the psychoanalytic developmental approach is dynamic, seeing development as a series of compromise formations. This gives depth, texture, and complexity to the developmental process, which-as we have tried to illustrate-is in line with new knowledge emerging from both neuroscience and developmental psychopathology. Many psychoanalytic accounts provide satisfying functionalist explanations of observed patterns of behavior and the observed characteristics of mental representation. These characteristics have supported developmental psychopathology over the last quarter of a century and will, we trust, continue to do so in the next.

We have striven to show that, beyond general characteristics, some specific insights of psychoanalysis should be preserved if developmental psychopathology is to retain its comprehensive picture of human psychological growth.

\section{Conclusions}

Psychoanalytic ideas remain radical and retain the potential to illuminate many aspects of developmental psychopathology. Some major tasks for psychoanalytically oriented clinician-researchers are

(a) to move away from enumerative inductivism and develop closer links with the alternative data gathering methods available in modern social and biological science;

(b) to define psychoanalytic constructs and techniques more tightly. This must include not only operational definitions but also the "unpacking" of overarching concepts, such as object relationships, and the specification of predictions: what remote or proximal variables account for the emergence of specific symptoms, and what is the interaction among predisposing variables and other contributory factors?

(c) to develop a tradition of "comparative psychoanalytic studies," where alternative frameworks are considered side by side in relation to the observations. This should be extended so that explanations from outside psychoanalysis are considered, because they may suggest better or complementary ways of understanding the data.

(d) related to the above, to become more sophisticated in thinking about interactions between the intrapsychic world and the environment (Rutter, 1993) and the processes of risk and trauma;

(e) to give much greater consideration to the wider social and cultural context within which object relations develop. For example, placing the individuated self at the peak of a developmental hierarchy is ethnocentric, as well as pathologizing a mode of functioning that may be adaptive in certain contexts.

(f) to focus on the relevance of psychoanalytic theory and treatment to the commu- 
nity at large. For example, psychoanalytic studies of multigenerational traumata have principally focused on survivors of the Holocaust (e.g., Kogan, 1995). Yet perhaps we could learn as much or more about this process from the study of African American communities in the United States, many of whose current problems could be seen in the context of our failures in terms of their history in North America as an enslaved group (e.g., Bass, Wyatt, \& Powell, 1982);

(g) to throw away the shackles of an overspecified theory and focus on the essential components of psychoanalytic psychological propositions.

If psychoanalysis is able to meet these challenges, then taking psychoanalytic ideas more seriously could have a very beneficial effect on epistemological and methodological aspects of developmental psychopathology. This particularly applies to the central notion that complex and, at times, conflicting representations of unconscious beliefs and affects created early in life influence behavior and experience throughout the lifetime. A widening perspective could, for example, lead to a shift in emphasis from self-report to narrative data; to a closer examination of patterns of narration, as opposed to observations of narrative content; to a greater concern with discordance and conflict among response systems, rather than a single-minded search for congruence and consistency. Psychoanalytic theory is alive, and its potential for enriching our understanding of developmental psychopathology has not been fully exploited in the century that has just closed.

\section{References}

American Psychoanalytic Association. (1998). Membership survey of the American Psychoanalytic Association. New York: Author.

Bass, B., Wyatt, G., \& Powell, G. (1982). The AfroAmerican Family. New York: Grune \& Stratton.

Bechara, A., Tranel, D., Damasio, H., Adolphs, R., Rockland, C., \& Damasio, A. (1995). Double dissociation of conditioning and declarative knowledge relative to the amygdala and hippocampus in humans. Science, 29, 1115-1118.

Beebe, B., Lachmann, F., \& Jaffe, J. (1997). Motherinfant interaction structures and presymbolic self and object representations. Psychoanalytic Dialogues, 7, 113-182.

Berger, L. S. (1985). Psychoanalytic theory and clinical practice: What makes a theory consequential for practice? Hillsdale, NJ: Analytic Press.

Blatt, S. J., \& Bers, S. A. (1993). The sense of self in depression: A psychodynamic perspective. In Z. V. Segal \& S. J. Blatt (Eds.), Self representation and emotional disorders: Cognitive and psychodynamic perspectives (pp. 171-210). New York: Guilford.

Blatt, S. J., \& Blass, R. (1996). Relatedness and self definition: A dialectic model of personality development. In G. G. Noam \& K. W. Fischer (Eds.), Development and vulnerabilities in close relationships (pp. 309338). Mahwah, NJ: Erlbaum.

Blatt, S. J., Quinlan, D. M., Pilkonis, P. A., \& Shea, M. T. (1995). Impact of perfectionism and need for approval on the brief treatment of depression: The National Institute of Mental Health Treatment of Depression Collaborative Research Program revisited. Journal of Consulting and Clinical Psychology, 63, 125-132.

Blatt, S. J., Zuroff, D. C., Bondi, C. M., Sanislow, C. A., \& Pilkonis, P. A. (1998). When and how per- fectionism impedes the brief treatment of depression: Further analyses of the National Institute of Mental Health treatment of depression collaborative research program. Journal of Consulting and Clinical Psychology, 66, 423-428.

Brenner, C. (1982). The mind in conflict. New York: International Universities Press.

Bretherton, K., \& Munholland, K. A. (1999). Internal working models in attachment relationships: A construct revisited. In J. Cassidy \& P. R. Shaver (Eds.), Handbook of attachment: Theory, research and clinical applications (pp. 89-114). New York: Guilford.

Brewin, C. R., Andrews, B., \& Gotlib, I. H. (1993). Psychopathology and early experience: A reappraisal of retrospective reports. Psychological Bulletin, 113, 82-98.

Caspi, A., \& Moffitt, T. W. (1993). When do individual differences matter? A paradoxical theory of personality coherence. Psychological Inquiry, 4, 247-271.

Caspi, A., \& Moffitt, T. E. (1995). The continuity of maladaptive behavior: From description to understanding in the study of antisocial behavior. In D. Cicchetti \& D. Cohen (Eds.), Developmental psychopathology: Vol 2. Risk, disorder, and adaption (pp. 472-511). New York: Wiley.

Champion, L. A., Goodall, G. M., \& Rutter, M. (1995). Behavioural problems in childhood and stressors in early adult life: A 20 year follow-up of London school children. Psychological Medicine, 25, 231246.

Churchland, P. S., Ramachandran, V. S., \& Sejnowski, T. J. (1994). A critique of pure vision. In C. Koch \& J. L. Davis (Eds.), Large-scale neuronal theories of the brain (pp. 23-60). Cambridge, MA: MIT Press.

Cicchetti, D., \& Rogosch, F. A. (1996). Equifinality and 
multifinality in developmental pscyhopathology. Development and Psychopathology, 8, 597-600.

Cicchetti, D., \& Rogosch, F. A. (1997). The role of selforganization in the promotion of resilience in maltreated children. Development and Psychopathology, 9, 797-815.

Cicchetti, D., Rogosch, F. A., Lynch, M., \& Holt, A. D. (1993). Resilience in maltreated children: Processes leading to adaptive outcome. Development and Psychopathology, 5, 629-647.

Crews, F. (1993, November 18). The unknown Freud. New York Review of Books.

Davidson, R. (1992). Emotion and affective style: Hemispheric substrates. Psychological Science, 3, 39-43.

Dozier, M., \& Kobak, R. (1992). Psychophysiology in attachment interviews: Converging evidence for deactivating strategies. Child Development, 63, 14731480.

Edelman, G. (1992). Bright air, brilliant fire. New York: Basic Books.

Elkin, I. (1994). The NIMH treatment of depression collaborative research program: Where we began and where we are. In A. E. Bergin \& S. L. Garfield (Eds.), Handbook of psychotherapy and behavior change (pp. 114-139). New York: Wiley.

Emde, R. N. (1988). Development terminable and interminable. I. Innate and motivational factors from infancy. International Journal of Psycho-Analysis, 69, 23-42.

Eysenck, H. J. (1952). The effects of psychotherapy: An evaluation. Journal of Consulting Psychology, 16, 319-324.

Farrington, D. P., Barnes, G. C., \& Lambert, S. (1996) The concentration of offending in families. Legal and Criminological Psychology, 1, 47-63.

Fazio, R., Jackson, J. R., Dunton, B., \& Williams, C. J. (1995). Variability in automatic activation as an unobtrusive measure of racial attitudes: A bona fide pipeline? Journal of Personality and Social Psychology, 69, 1013-1027.

Fergusson, D. M., \& Lynskey, M. T. (1996). Adolescent resiliency to family adversity. Journal of Child Psychology and Psychiatry, 37, 281-292.

Fischer, K. W., \& Ayoub, C. (1994). Affective splitting and dissociation in normal and maltreated children: Developmental pathways for self in relationships. In D. Cicchetti \& S. L. Toth (Eds.), Rochester Symposium on Developmental Psychopathology: Vol. 5. Disorders and dysfunctions of the self (pp. 149-222). Rochester, NY: University of Rochester Press.

Fonagy, P. (1982). Psychoanalysis and empirical science. International Review of Psychoanalysis, 9, 125-145.

Fonagy, P. (1989). On the integration of psychoanalysis and cognitive behaviour therapy. British Journal of Psychotherapy, 5, 557-563.

Fonagy, P. (in press). The relationship of theory and practice in psychodynamic therapy. Journal of Clinical Child Psychology.

Fonagy, P., Leigh, T., Steele, M., Steele, H., Kennedy, R., Mattoon, G., Target, M., \& Gerber, A. (1996). The relation of attachment status, psychiatric classification, and response to psychotherapy. Journal of Consulting and Clinical Psychology, 64, 22-31.

Fonagy, P., \& Target, M. (1997). Perspectives on the recovered memories debate. In J. Sandler \& P. Fonagy (Eds.), Recovered memories of abuse: True or false? (pp. 183-216). London: Karnac Books.

Fonagy, P., Target, M., Steele, M., \& Gerber, A. (1995).
Psychoanalytic perspectives on developmental psychopathology. In D. Cicchetti \& D. J. Cohen (Eds.), Developmental psychopathology: Theory and methods (Vol. 1, pp. 504-554). New York: Wiley.

Freud, A. (1974). A psychoanalytic view of developmental psychopathology. In The writings of Anna Freud (Vol. 8, pp. 119-136). New York: International Universities Press.

Freud, S. (1895). Project for a scientific psychology. In J. Strachey (Ed.), The standard edition of the complete psychological works of Sigmund Freud (Vol. 1, pp. 281-293). London: Hogarth Press.

Freud, S. (1900). The interpretation of dreams. In J. Strachey (Ed.), The standard edition of the complete psychological works of Sigmund Freud (Vols. 4-5, pp. 1-715). London: Hogarth Press.

Freud, S. (1905). Fragment of an analysis of a case of hysteria. In J. Strachey (Ed.), The standard edition of the complete psychological works of Sigmund Freud (Vol. 7, pp. 7-122). London: Hogarth Press.

Freud, S. (1909a). Analysis of a phobia in a five-year-old boy. In J. Strachey (Ed.), The standard edition of the complete psychological works of Sigmund Freud (Vol. 10, pp. 1-147). London: Hogarth Press.

Freud, S. (1909b). Notes upon a case of obsessional neurosis. In J. Strachey (Ed.), The standard edition of the complete psychological works of Sigmund Freud (Vol. 10, pp. 153-320). London: Hogarth Press.

Freud, S. (1912). Recommendations to physicians practising psychoanalysis. In J. Strachey (Ed.), The standard edition of the complete psychological works of Sigmund Freud (Vol. 12, pp. 109-120). London: Hogarth Press.

Freud, S. (1915). Mourning and melancholia. In J. Strachey (Ed.), The standard edition of the complete psychological works of Sigmund Freud (Vol. 14, pp. 237-258). London: Hogarth Press.

Freud, S. (1919). "A child is being beaten": A contribution to the study of the origin of sexual perversion. In J. Strachey (Ed.), The standard edition of the complete psychological works of Sigmund Freud (Vol. 17, pp. 175-204). London: Hogarth Press.

Freud, S. (1920). Beyond the pleasure principle. In J. Strachey (Ed.), The standard edition of the complete psychological works of Sigmund Freud (Vol. 18, pp. 1-64). London: Hogarth Press.

Freud, S., \& Breuer, J. (1895). Studies on hysteria. In J. Strachey (Ed.), The standard edition of the complete psychological works of Sigmund Freud (Vol. 2, pp. 1-305). London: Hogarth Press.

Frosh, S. (1997). For and against psychoanalysis. London: Routledge.

Gedo, J. E. (1979). Beyond interpretation. New York: International Universities Press.

Gergely, G. (1991). Developmental reconstructions: Infancy from the point of view of psychoanalysis and developmental psychology. Psychoanalysis and Contemporary Thought, 14, 3-55.

Goldfried, M. R. (1995). From cognitive-behavior therapy to psychotherapy integration. New York: Springer.

Goldfried, M. R., \& Newman, C. F. (1992). A history of psychotherapy integration. In J. C. Norcross \& M. R. Goldfried (Eds.), Handbook of psychotherapy integration (pp. 44-91). New York: Basic Books.

Goschke, T., \& Kuhl, J. (1993). Representations of intentions: Persisting activation in memory. Journal of Ex- 
perimental Psychology: Learning, Memory and Cognition, 19, 1211-1226.

Gray, J. A. (1990). Brain systems that mediate both emotion and cognition. Cognition and Emotion, 4, 269288.

Green, A. (1999). Consilience and rigour. Neuro-Psychoanalysis, 1, 40-44.

Greenwald, A. G., \& Banaji, M. (1995). Implicit social cognition: Attitudes, self-esteem, and stereotypes. Psychological Review, 102, 4-27.

Grünbaum, A. (1984). The foundations of psychoanalysis: A philosophical critique. Berkeley, CA: University of California Press.

Hartup, W. W., \& Stevens, N. (1997). Friendships and adaptation in the life course. Psychological Bulletin, $121,355-370$

Hempel, C. (1965). Aspects of scientific explanation. New York: Lasalle.

Hirshberg, L., \& Svejda, M. (1990). When infants look to their parents: II. Twelve-month-olds' response to conflicting parental emotional signals. Child Development, 61, 1187-1191.

Hopkins, J. (1992). Psychoanalysis, interpretation, and science. In J. Hopkins \& A. Saville (Eds.), Psychoanalysis, mind and art: Perspectives on Richard Wollheim (pp. 3-34). Oxford: Blackwell.

Johnson, J. G., Cohen, P., Brown, J., Smailes, E. M., \& Bernstein, D. P. (1999). Childhood maltreatment increases risk for personality disorders during early adulthood. Archives of General Psychiatry, 56, 600605.

Johnson-Laird, P. N., \& Byrne, R. M. (1993). Precis of deduction. Behavioural and Brain Sciences, 16, 323380.

Jones, E. E. (1993). How will psychoanalysis study itself? Journal of the American Psychoanalytic Association, 41, 91-108.

Jones, E. E. (1997). Modes of therapeutic action. International Journal of Psycho-Analysis, 78, 1135-1150.

Kandel, E. R. (1998). A new intellectual framework for psychiatry. American Journal of Psychiatry, 155, 457-469.

Kandel, E. R. (1999). Biology and the future of psychoanalysis: A new intellectual framework for psychiatry revisited. American Journal of Psychiatry, 156, 505524.

Kendler, K. S., Neale, M. C., Kessler, R. C., Heath, A C., \& Eaves, L. J. (1993). A longitudinal twin study of personality and major depression in women. Archives of General Psychiatry, 50, 853-862.

Kendler, K. S., Neale, M. C., Prescott, C. A., Kessler, R. C., Heath, A. C., Corey, L. A., \& Eaves, L. J. (1996). Childhood parental loss and alcoholism in women: A causal analysis using a twin-family design. Psychological Medicine, 26, 79-95.

Kihlstrom, J. (1987). The cognitive unconscious. Science, 237, 1445-1452.

Kinsbourne, M., \& Hicks, R. E. (1979). Mapping cerebra functional space: Competition and collaboration in human performance. In M. Kinsbourne (Ed.), Assymmetrical function of the brain (pp. 267-273). Cambridge: Cambridge University Press.

Klein, M., Heimann, P., Issacs, S., \& Riviere, J. (Eds.) (1946). Developments in psychoanalysis. London: Hogarth Press.

Kogan, I. (1995). The cry of mute children: A psychoanalytic perspective of the second generation of the holocaust. London: Free Association.
Kohut, H. (1984). How does analysis cure? Chicago: University of Chicago Press.

Krause, R. (1997). Allgemeine psychoanalytische Krankheitslehre: Grundlagen. Stuttgart, Germany: Kohlhammer.

Lashley, K. S. (1929). Brain mechanisms and intelligence: A quantitative study of injuries to the brain. Chicago: University of Chicago Press.

LeDoux, J. (1995a). Emotion: Clues from the brain. Annual review of Psychology, 46, 209-235.

LeDoux, J. E. (1995b). Emotion: Clues from the brain. Annual Review of Psychology, 46, 209-235.

Levine, S., Haltmeyer, G. C., Kaas, G. G., \& Penenberg, V. H. (1967). Physiological and behavioural effects of infantile stimulation. Physiology and Behavior, 2, $55-63$.

Liu, D., Diorio, J., Tannenbaum, B., Caldji, C., Francis, D., Freedman, A., Sharma, S., Pearson, D., Plotsky, P. M., \& Meaney, M. J. (1997). Maternal care, hippocampal glucocorticoid receptors, and hypothalamicpituitary-adrenal responses to stress. Science, 277, $1659-1662$.

Lyons-Ruth, K., \& Jacobovitz, D. (1999). Attachment disorganization: Unresolved loss, relational violence and lapses in behavioral and attentional strategies. In J. Cassidy \& P. R. Shaver (Eds.), Handbook of attachment theory and research (pp. 520-554). New York: Guilford.

Macfie, J., Toth, S. L., Rogosch, F. A., Robinson, J., Emde, R. N., \& Cicchetti, D. (1999). Effect of maltreatment on preschoolers' narrative representations of responses to relieve distress and of role reversal. Developmental Psychology, 35, 460-465.

Mahler, M. S., Pine, F., \& Bergman, A. (1975). The psychological birth of the human infant: Symbiosis and individuation. New York: Basic Books.

Main, M., \& Morgan, H. (1996). Disorganization and disorientation in infant strange situation behavior: Phenotypic resemblance to dissociative states. In L. K. Michelson \& W. J. Ray (Eds.), Handbook of dissociation: Theoretical, empirical, and clinical perspectives (pp. 107-138). New York: Plenum Press.

Malan, D., \& Osimo, F. (1992). Psychodynamics, training and outcome in brief psychotherapy. London: Butterworth-Heinemann.

Mandler, G. (1997). Human nature explored. New York: Oxford University Press.

Mayes, L. C., \& Spence, D. P. (1994). Understanding therapeutic action in the analytic situation: A second look at the developmental metaphor. Journal of the American Psychoanalytic Association, 42, 789-816.

McEwen, B. S., \& Sapolsky, R. M. (1995). Stress and cognitive function. Current Opinion in Neurobiology, 5, 205-216.

Milner, B., Squire, L. R., \& Kandel, E. R. (1998). Cognitive neuroscience and the study of memory. Neuron Review, 20, 445-468.

Morris, J. S., Ohman, A., \& Dolan, R. J. (1998). Conscious and unconscious emotional learning in the human amygdala. Nature, 393, 467-470.

Murphy, S. T., Monahan, J. L., \& Zajonc, R. (1995). Additivity of nonconscious affect: Combined effects of priming and exposure. Journal of Personality and Social Psychology, 69, 589-602.

Nemeroff, C. B. (1996). The corticotropin-releasing factor (CRF) hypothesis of depression: New findings and new directions. Molecular Psychiatry, 1, 326-342.

Newman, L. S., Duff, K., \& Baumeister, R. (1997). A 
new look at defensive projection: Thought suppression, accessibility, and biased person perception. Journal of Personality and Social Psychology, 72, 980-1001.

Nisbett, R. E., \& Wilson, T. D. (1977). Telling more than we can know: Verbal reports on mental processes. Psychological Review, 84, 231-259.

O’Connor, T. G., Deater-Deckard, K., Fulker, D., Rutter, M., \& Plomin, R. (1998). Genotype-environment correlations in late childhood and early adolescence: Antisocial behavioral problems and coercive parenting. Developmental Psychology, 34, 970-981.

O’Connor, T. G., Rutter, M., \& Kreppner, J. (in press) The effects of global severe privation of cognitive competence: Extension and longitudinal follow-up. Child Development.

Oppenheim, D., Emde, R., \& Warren, S. (1997). Children's narrative representations of mothers: Their development and associations with child and mother adaptation. Child Development, 68, 127-138.

Plomin, R., \& Daniels, D. (1987). Why are children in the same family so different from one another? Behavioral and Brain Sciences, 10, 1-16.

Plomin, R., DeFries, J. C., McLearn, G. E., \& Rutter, R. (1997). Behavioral genetics (3rd ed.). New York: W. H. Freeman.

Plotsky, P. M., \& Meaney, M. J. (1993). Early, postnatal experience alters hypothalamic corticotropin-releas ing factor (CRF) mRNA, median eminence CRF content and stress-induced release in adult rats. Brain Research. Molecular Brain Research, 18, 195-200.

Quinton, D., Pickles, A., Maughan, B., \& Rutter, M. (1993). Partners, peers, and pathways: Assortative pairing and continuities in conduct disorder. Development and Psychopathology, 5, 763-783.

Quinton, D., \& Rutter, M. (1988). Preventing breakdown: The making and breaking of inter-generational links. Aldershot, England: Avebury.

Rogers, J. H., Widiger, T., \& Krupp, A. (1995). Aspects of depression associated with borderline personality disorder. American Journal of Psychiatry, 152, 168270.

Rosch, E. (1978). Principles of categorization. In E. Rosch \& B. B. Floyd (Eds.), Cognition and categorization (pp. 28-49). Hillsdale, NJ: Erlbaum.

Rowe, D. (1994). The limits of family influence: Genes, experience and behaviour. New York: Guilford Press.

Ruben, D. (Ed.). (1993). Explanation. Oxford: Oxford University Press.

Rumelhart, D. E., \& McClelland, J. L. (1986). Parallel distributed processing. Cambridge, MA: MIT Press.

Rutter, M. (1981). Maternal deprivation reassessed (2nd ed.). Harmondsworth, England: Penguin.

Rutter, M. (1993). Developmental psychopathology as a research perspective. In D. Magnusson \& P. Casaer (Eds.), Longitudinal research on individual development: Present status and future perspectives (pp. 127-152). New York: Cambridge University Press.

Rutter, M. (1999). Psychosocial adversity and child psychopathology. British Journal of Psychiatry, 174, 480-493.

Rutter, M., Champion, L., Quinton, D., Maughan, B., \& Pickles, A. (1995). Understanding individual differences in environmental risk exposure. In P. Moen, G. H. Elder Jr., \& K. Luscher (Eds.), Examining lives in context: Perspectives on the ecology of human development (pp. 61-93). Washinton, DC: American Psychological Association.
Rutter, M., Dunn, J., Plomin, R., Simonoff, E., Pickles, A., Maughan, B., Ormel, J., Meyer, J., \& Eaves, L. (1997). Integrating nature and nurture: Implications of person-environment correlations and interactions for developmental psychology. Development and Psychopathology, 9, 335-364.

Rutter, M., \& Smith, D. J. (Eds.). (1995). Psychosocial disorders in young people. Time trends and their causes. Chichester, England: Wiley.

Ryle, A. (1994). Psychoanalysis and cognitive analytic therapy. British Journal of Psychotherapy, 10, 402 405.

Sandler, J. (1962). The Hampstead Index as an instrument of psychoanalytic research. Internal Journal of Psycho-Analysis, 43, 287-291.

Sandler, J. (1983). Reflections on some relations between psychoanalytic concepts and psychoanalytic practice. International Journal of Psycho-Analysis, 64, 35-45.

Sandler, J., \& Fonagy, P. (Eds.). (1997). Recovered memories of abuse: True or false? London: Karnac Books.

Scarr, S. (1992). Developmental theories for the 1990s: Development and individual differences. Child Development, 63, 1-19.

Schore, A. N. (1999). Commentary. Neuro-Psychoanalysis, 1, 49-55.

Sroufe, L. A., Egeland, B., \& Kreutzer, T. (1990). The fate of early experience following developmental change: Longitudinal approaches to individual adaptation in childhood. Child Development, 61, 13631373.

Sroufe, L. A., \& Fleeson, J. (1988). The coherence of family relationships. In R. A. Hinde \& J. StevensonHinde (Eds.), Relationships within families: Mutual influences (pp. 27-47). Oxford: Clarendon Press.

Suess, G. J., Grossmann, K., \& Sroufe, L. A. (1992). Effects of infant attachment to mother and father on quality of adaptation in preschool: From dyadic to individual organisation of self. International Journal of Behavioral Development, 15, 43-65.

Toth, S. L., Cicchetti, D., Macfie, J., \& Emde, R. N. (1997). Representations of self and other in the narratives of neglected, physically abused, and sexually abused preschoolers. Development and Psychopathology, 9, 781-796.

Tronick, E. (1989). Emotions and emotional communication in infants. American Psychologist, 44, 112-119.

Ullmann, L. P., \& Krasner, L. (1969). A psychological approach to abnormal behavior. Englewood Cliffs, NJ: Prentice-Hall.

Underwood, G. (Ed.). (1996). Implicit cognition. New York: Oxford University Press

Wallerstein, R. S. (1992). The common ground of psychoanalysis. Northvale, NJ: Jason Aronson.

Wason, P. C., \& Johnson-Laird, P. N. (1972). Psychology of reasoning: Structure and content. Cambridge, MA: Harvard University Press.

Watson, J. B. (1930). Behaviorism (Rev. ed.). New York: Norton.

Webster, R. (1995). Why Freud was wrong: Sin, science and psychoanalysis. London: HarperCollins.

Westen, D. (1990). Towards a revised theory of borderline object relations: Contributions of empirical research. International Journal of Psycho-Analysis, 71, 661-694.

Westen, D. (1991). Social cognition and object relations. Psychological Bulletin, 109, 429-455.

Westen, D. (1999). Psychology: Mind, brain, and culture (2nd ed.). New York: Wiley. 
Westen, D. (in press-a). The scientific legacy of Sigmund Freud: Toward a psychodynamically informed psychological science. Psychological Bulletin.

Westen, D. (in press-b). The scientific status of unconscious processes: Is Freud really dead? Journal of the American Psychoanalytic Association.

Westen, D., Moses, M. J., Silk, K. R., Lohr, N. E., Cohen, R., \& Segal, H. (1992). Quality of depressive experience in borderline personality disorder and major depression: When depression is not just depression. Journal of Personality Disorders, 6, 383-392.

Westen, D., Muderrisoglu, S., Fowler, C., Shedler, J., \& Koren, D. (1997). Affect regulation and affective experience: Individual differences, group differences, and measurement using a Q-sort procedure. Journal of Consulting and Clinical Psychology, 65, 429439.

Wilson, T. D., \& Schooler, J. W. (1991). Thinking too much: Introspection can reduce the quality of preferences and decisions. Journal of Personality and Social Psychology, 60, 181-192.

Wittgenstein, L. (1969). The blue and brown books. Oxford: Blackwell.

Wolpe, J. (1969). The practice of behavior therapy. New York: Pergamon.

Wong, P., Bernat, E., Bunce, S., \& Shevrin, H. (in press). Brain indices of nonconscious associative learning. Consciousness and Cognition. 